HISTORY OF MEDICINE

\title{
Scurvy in the British Mercantile Marine in the 19th century, and the contribution of the Seamen's Hospital Society
}

\author{
G C Cook
}

Postgrad Med J 2004;80:224-229. doi: 10.1136/pgmj.2003.011122

When long voyages in sailing vessels were commonplace, scurvy was a major health hazard in mariners of all nations. The observations of James Lind (1716-94) and others indicated that citrus fruits had both a preventive and curative role in this disease. In the light of this work, by 1800 the disease had been virtually eliminated from Britain's Royal Navy. However, it continued in the merchant navies of all nations until the latter half of the 19th century. In 1867, the Merchant Shipping Amendment Act was passed by the British Parliament largely as a result of a concerted effort by the Seamen's Hospital Society (SHS), one of whose physicians, Harry Leach (1836-79) was the major proselytiser for improved conditions in the merchant service. Examination of the SHS records before and after this event demonstrate a marked reduction in the prevalence of scurvy in the Port of London. Although other factors - such as the introduction of steam ships, which resulted in faster voyages - were clearly important, the compulsory administration of genuine lime juice under supervision in the merchant service seems to have exerted a significant effect.

Correspondence to:

Professor Gordon C Cook, Fellowship of Postgraduate Medicine, 12 Chandos Street, London WIG 9DR, UK

Submitted 11 June 2003 Accepted

10 September 2003
$\mathrm{T}$ he prevalence of scurvy in ancient times remains unclear ${ }^{1-3}$; it seems likely that the disease did not reach "epidemic" proportions in seafarers until the advent of long sea voyages to and from Europe to India, and the East Indies. It was also endemic in certain locations on shore especially among the poor; potential recruits to the Royal Navy were sometimes rejected as chronic scorbutics. ${ }^{4}$ The very high mortality rate during Anson's circumnavigation in 1740-4 (fig 1) did much to emphasise the importance of this disease in mariners. ${ }^{5-7}$ A small clinical trial by James Lind (1716-94) in $1747^{8-10}$ established that this was primarily a disease which could be cured by citrus fruits (fig 2). Subsequent work by Gilbert Blane (1749-1834) and Thomas Trotter $(1760-1832)^{11} 12$ established the accuracy of Lind's observations; indeed, Blane's 1815 summary confirmed the virtual disappearance of scurvy from the Royal Navy. ${ }^{13}$ An extensive literature on this subject documents these important developments. ${ }^{14-16}$

By the mid-19th century, the disease had largely disappeared from the land-based British population. However, Robert Barnes (physician to the Seamen's Hospital Society's (SHS)
Hospital-ship Dreadnought) in an excellent historical account of scurvy in Britain and in British vessels pointed out that "In the spring of 1823 scurvy [still] prevailed in the Millbank penitentiary ... being caused by a diet of which fresh succulent vegetables formed no part". ${ }^{17}$ "Many similar instances [he wrote] occur in the reports of the Inspectors of Prisons for the years 1836, 1837 and 1838". "The excellent dietaries now adopted in our gaols, workhouses, and other public institutions have abolished scurvy [he wrote], and to the present race of officials the disease is unknown".

Although not therefore a major killer in the Royal Navy by the 19th century, scurvy occasionally produced serious debility, thereby significantly reducing the functional reserve of crews. The disease remained however, a problem in warships of other nationalities until the latter 19th century; for example, a report received in Britain in 1867 recorded 13 deaths among 100 cases of the disease on the Spanish frigate Resolucion - which had been engaged in "blockading the coasts of Chili [sic] and Peru". A Times reporter considered this fact, "more remarkable as [the outbreak had occurred in men of] a herbivorous and wine drinking nation"! $!^{18}$

Elimination of scurvy was not to be the case in the British merchant navy-several SHS annual reports (see below) documented the high prevalence of this disease in merchant seamen in the Port of London; a report covering 1841, for example, recorded: "Out of the number of Asiatic Seamen ['Lascars'] introduced to this port, many most pitiable objects have been brought to the Dreadnought, afflicted with scurvy in its most aggravated form" ${ }^{\prime 1} .{ }^{19}$ In 1838 the Committee of the SHS encouraged George Budd FRS (1808-82) one of their physicians to determine the cause(s) and cure, and he also wrote an erudite review in which he confirmed that this was a dietary disease, and that lime and lemon juice had a role in both prevention and cure. ${ }^{20-22}$

\section{INCIDENCE OF, AND REASONS FOR, PERSISTENCE OF SCURVY IN THE MERCANTILE MARINE}

Figure 3 summarises the number of cases of scurvy encountered in the latter half of the 19th century by the SHS $^{23}$ in their hospitals at Greenwich and the Albert Dock (the Branch Hospital of the Dreadnought which was opened in 1892). The Dreadnought hospital-ship had been succeeded in 1870 by the land-based Dreadnought [Seamen's] Hospital. Most illness in the world's merchant seamen when in the London docks, was referred to one of these institutions..$^{25}$ 


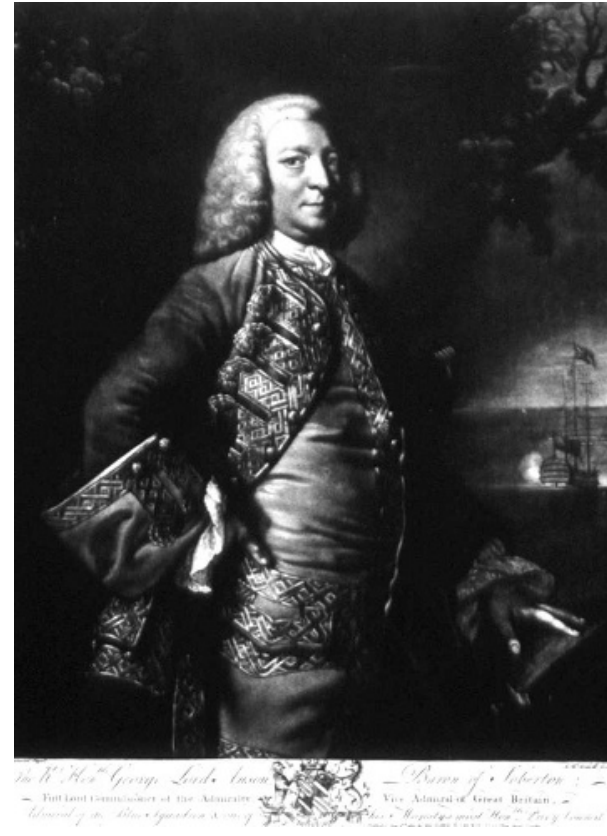

Figure 1 Admiral Lord George Anson (1697-1762) whose circumnavigation in 1740-44 produced an extremely high mortality in his crew, due largely to scurvy (courtesy The Seamen's Hospital Society).

Many cases of scurvy were severe, and during this period (1852-1905) there were 18 deaths.

The SHS was founded in 1821 (that is, soon after the Napoleonic Wars) with the objective of caring for the physical and spiritual requirements of the merchant sailors of all nations who were roaming around the Port of London in large numbers. ${ }^{25} 26$ The first hospital-ship, the Grampus was used until 1831; this was succeeded by a larger hulk, the Dreadnought (which had been a 104 gun ship and had served at Trafalgar) until 1857. The third hospital-ship, the Caledonia (renamed Dreadnought) was larger (120 guns) and served as the SHS hospital until 1870 when clinical facilities were transferred to dry land in what had previously been the Infirmary of the Royal Hospital, Greenwich. Britain's merchant seamen, like those of other nations, lived a most erratic existence-often being employed (frequently by ship owners who were often unscrupulous) for a single voyage only. ${ }^{27}$

On account of the continuing (unacceptable) prevalence of scurvy in the merchant service in the mid-19th century, The Times (referring to a Board of Trade correspondence published in June 1865 in collaboration with the SHS) launched a "campaign" in January $1866^{28}$ in an attempt to solve this problem which in the mind of the anonymous writer was endangering ships owing to disability of their crews as a result of scurvy. Persistence of the disease in the merchant ships the article emphasised, "could only be explained by great carelessness or indifference on the part of the shipowners". Correspondence between the Board of Trade and the Local Marine Boards, and others (1864-65) on scurvy in merchant ships since the sixth report of the Medical Officer of the Privy Council (dated 1863) (29 $^{2}$ based on a report by Robert Barnes is given in full in a detailed Parliamentary Paper dated 23 June $1865 .^{30}$ Much of this correspondence emanated from the SHS. The Medical Officer to the Privy Council commented "of the entire number of men received into the Sailors' Home at Poplar [in London's dockland], nearly half are, at the time of their admission, suffering more or less from scurvy, and ... perhaps a twentieth part seriously diseased with it ...". ${ }^{29}$ He continued, "Apart from the not
A

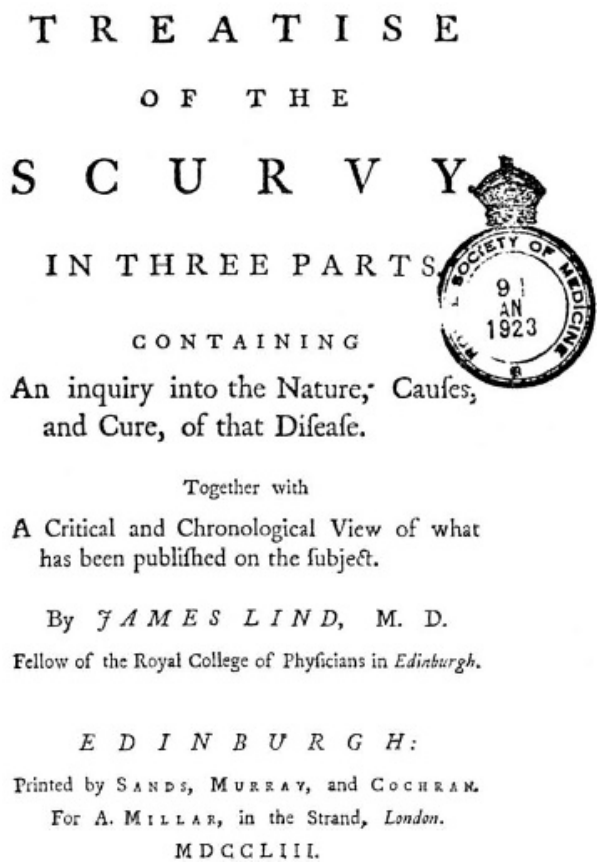

Figure 2 Title page of James Lind's A Treatise of the Scurvy in three parts, containing an Inquiry into the Nature, Causes, and Cure of that Disease. Together with a critical and chronological view of what has been published on the subject.

insignificant question ... of cruelty from master to servant ... the security of this country has on several occasions been imperilled by the disablement of the [Royal Navy] through scurvy, it may be presumed that the same cause will imperil the safety of our merchant ships". Scurvy (Barnes had commented) "may be prevalent in the forecastle, but it is never known in the cabin; if the captain and mates know how to preserve themselves, they know how to preserve their men". "Owners [he wrote], notwithstanding the law [that is, the Merchant Shipping Act of $1854^{31}$ ], will send forth their ships on long voyages without any provision of lime juice or with lime juice insufficient in quantity, or with lime juice the quality of which is bad"; and "captains, with half their crews more or less disabled, are known to run past St Helena or the Western Isles when a few hours' delay would obtain sufficient provisions to repair the mischief occasioned by first neglect". He stressed furthermore, that scurvy was then "entirely preventable" and that in the Royal Navy "... is now an almost unknown disease". Part 2 of the 1865 paper $^{30}$ gives details of inquiries which were ordered by the Board of Trade "in cases where scurvy has been known to exist on board Ship".

In his well argued account the writer of The Times article ${ }^{28}$ (the Medical Officer of the Dreadnought maintained that scurvy had actually increased in prevalence during the previous 12 years) considered that the cause of the disease was already well established (it was "one of the few diseases with the cause of which we are perfectly acquainted, and for which we possess an infallible preventive"); the contemporary high prevalence of the disease, he claimed, resulted from: (i) adulterated lime juice (it was "manufactured ... from tartaric and other acids, at a cheap cost, and flavoured with essence of lemon ...") (a Liverpool manufacturer was he claimed, in large part responsible), (ii) poor storage of supplies of lime juice (10\% spirit should be added and it should be kept in "moderately-sized glass bottles or stone 


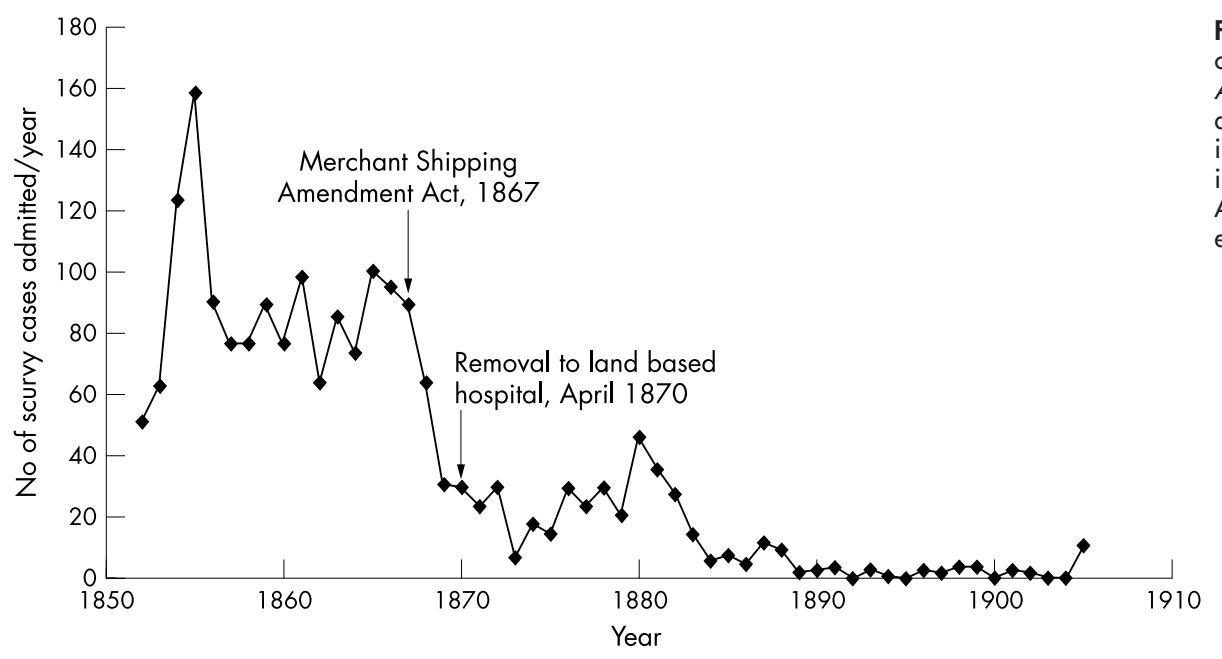

Figure 3 Annual admission rates for cases of scurvy to the Dreadnought and Albert Dock Hospitals between 1852 and 1905. A sharp decline took place immediately after Parliament introduced the Merchant Shipping Amendment Act in 1867; this was enforced on 1 January 1868.

jars"), and (iii) poor compliance (the standard(s) of discipline in the Mercantile Marine fell far short of that in the Royal Navy). The cure was "Good lime or lemon juice ... at the rate of from four to seven ounces a week ...". "These evils [the anonymous writer also concluded] are aggravated by the frequent disinclination of the crew to drink the juice regularly". However, the writer (erroneously) considered that the situation was "aggravated by bad water or bad meat"! He also agreed with the "Board of Trade [who], at the suggestion of the [SHS, had recommended] that inspectors [who should investigate all cases of the disease] should be appointed under the Mercantile Shipping Act ...". It was the view of the Medical Officer of the Privy Council that the intentions of the 1854 Act were "not likely to be altogether realized unless particular inspectional regard be had to breaches of the Act"; in the event that an inspection of a ship after a long voyage showing scurvy on board "inquiry under the Merchant Shipping Act should be held whether a punishable offence under that Act had been committed". Sadly, five out of seven local Marine Boards who had replied to the SHS had rejected the proposal of medical inspectors.

The magnitude of the problem (and its solution)-by providing good quality lime or lemon juice, preferably the latter (see below) —was highlighted in a series of letters to The Times from the pen of Harry Leach (1836-79), Resident Medical Officer on the Dreadnought hospital-ship..$^{32-40}$ He also emphasised that the majority of cases seen at that hospital had been contracted on British owned ships. It was "a mockery [he wrote] to talk about 'smart' ships, with miserably debilitated inmates, such as are constantly brought to us [at Greenwich], and it is equally futile to legislate about wood, iron, and tow if healthy vital force be not combined therewith". Another experience of the disease (emphasising the importance of good quality lime or lemon juice) came from John Picthall, a surgeon in "Her Majesty's Indian Service" ${ }^{\prime \prime 1}$ - he had, he wrote, had extensive experience of "scorbutic dysentery" at the European General Hospital at Howrah, Calcutta. A Deputy Inspector-General of the Royal Navy (R Armstrong) - based at Chatham, but with extensive experience in "nearly all parts of the world"-also gave his view ${ }^{42}$; he too contrasted the health of "seamen in our merchant service" with those in the Royal Navy, and emphasised the outstanding value of lime juice-which must be consumed under observation! The breakdown of the 1854 Act (he considered) lay jointly with the ship owners (because they sent their ships to sea poorly victualled, and without satisfactory supplies of lime juice), and the Board of Trade (which did "not exercise due vigilance and supervision over the supplies to merchant ships"). The Times leading article also provoked a letter from a master mariner ("Limejuice") who had himself suffered from scurvy ${ }^{43}$; in his opinion the "owners and captains [were] not so black as they [were] painted"; the real problem lay with the sailors who would "not stay by their ships in harbour" but changed vessels at each port! An anonymous writer to the British Medical Journal again emphasised that the problem affected British vessels ${ }^{44}$; 12 men suffering from scurvy had recently been taken into the Dreadnought hospital-ship from two recently arrived vessels from Calcutta-which had taken 135 and 149 days respectively over their homeward bound voyages. Serious doubts concerning the quality of lime juice, and the prevailing frequency of its administration were again raised; these reservations were born out at an inquest at a Board of Trade inquiry on one of these men who actually died of the disease (although he also had cirrhosis and tuberculosis); it was also recommended that "some action should be taken by the Local Marine Boards in all ports", with a view to the inspection of lime juice shipped for the "use of seamen". ${ }^{45}$

\section{QUALITY OF LIME JUICE}

Both Budd and Leach (see above) had, among others, stressed that lime (or lemon) juice of good quality was the correct preventive/curative agent for scurvy. This view had also been echoed by most contemporary writers. Commenting on the outcome of yet another inquest (see below), W B Harrison ${ }^{46}$ attested that he had personally supplied good quality lime juice to the St Andrew's Castle (which had had five cases of severe scurvy on board ${ }^{47}$ - and that this remained satisfactory at analysis some 1214 months later. This short letter immediately brought forth a rebuttal from Leach $^{48}$; tests had, he claimed, shown that "... the fluid was not lime-juice at all[!]. It was either citric acid and water, or alternatively lemon juice and water, but [it was believed to be] merely citric acid and water". Analysis of lime juice at this time was far from satisfactory. ${ }^{47}$ Leach had merely reported on the colour, smell, consistence, specific gravity, and content of citric, sulphuric, tartaric, oxalic, and acetic acids; from this he reported: "... that this lemon juice is at least one-third ... weaker than any lemon juice yet analysed by us ..."; and he concluded "(1) That this mixture consists of 2 parts lemon juice and 1 part water, or (2) that it is simply a solution of citric acid". In the first half of the 19th century, the Royal Navy had issued either the preserved juice of lemons or Mediterranean sweet lime; from 1860 onwards, they had used the preserved juice of the West Indian (usually Jamaican) sour lime-which contained lower antiscorbutic activity ${ }^{49}{ }^{50}$ Further support for the provision of supplies of good quality juice on board merchant ships came from HW 
(a Commander in the Merchant Service who had 16 years experience on "long voyage" ships) $)^{51}$; "that the lime juice is often of inferior quality has long been patent to the seafaring public" he wrote; in his opinion, owing principally to poor storage, "... the juice goes bad just when most required-viz, at the latter part of the voyage". He too re-emphasised poor compliance; discipline was undoubtedly inferior in the Mercantile Marine when compared with that in the Royal Navy. There can be no doubt that the vitamin C content of lime/lemon juice was lowered after a long voyage (which applied to the Royal Navy also) even when storage facilities were excellent (see below), but this must have been proportional to its initial content.

\section{ALTERNATIVE VIEWS ON CAUSATION/CURE OF SCURVY}

The true aetiology of scurvy continued to be a contentious matter. Not all observers were of the opinion that good quality lime (or lemon) juice was the sole solution to the problem. Both Picthall ${ }^{41}$ and King ${ }^{52}{ }^{53}$ for example, favoured potatoes as a cure; the latter wrote of Sir F L M'Clintock's Arctic expedition (on The Fox) in which "the only death from scurvy occurred to one man who ... disliked the preserved potato". King felt that potatoes afforded the best cure; it was wrong (he contended) that ship owners should be obliged by the Act to provide lime juice to all men under their care, when preserved potatoes were available. The mariner who signed himself "Limejuice" also favoured "preserved potatoes" ${ }^{43}$ But the major protagonist for potatoes as the cure for scurvy was undoubtedly W D Stone, a Fellow of the Royal College of Surgeons. ${ }^{54-57}$ Stone was of the opinion that cooking did not diminish the antiscorbutic quality of the potato: "... this vegetable is equally effective when cooked, and certainly much more palatable ...". "In several prisons [as Barnes (see above) had written] the occurrence of scurvy has wholly ceased on the addition of a few pounds of potatoes being made to the weekly dietary". "Wine [he continued] is also decidedly, though not infallibly, antiscorbutic". Statistics [showed, Stone wrote] that "the number of cases of scurvy admitted on the Dreadnought [in 1865; fig 3] was in excess of any previous year" (a statement which was not true); he therefore also sought an amendment of the 1854 Mercantile Marine Act, and this further correspondence seems to have been "taken on board" by the Board of Trade.

The possibility that scurvy was a contagious disease also received strong support ${ }^{58-62}$; for example, the master of the Royal Sovereign, which had sailed from Bombay to Falmouth, on which an "outbreak" of scurvy had occurred, considered at an inquest that "the disease was introduced into the ship by a man ... who joined at Bombay, where he had been in the hospital under treatment for scurvy". ${ }^{63}$ Contaminated water was another candidate for causation of the disease; HW considered that water supplied to ships in "Madras Roads", although appearing "good and clear" when taken on board was "... black and very offensive to the taste and smell" when the ship has not "been long at sea". ${ }^{51}$ The Times considered that "the outbreak of the disease [on the bark Emily Flinn which had recently arrived in Plymouth from Moulmein (Myanmar, formerly Burma)] could be attributed to bad water put on board at Moulmein" ${ }^{58-62}$ The jury which investigated this case however, returned a verdict of: "Death from natural causes, accelerated by a long voyage and the excessive use of salt meat".

However, Stone, who rightly considered that land and sea scurvy were identical, commented "Dr [George] Budd [see above], probably the highest authority on this disease says ... that scurvy is caused neither by contagion, nor by cold weather, nor by impurity of the air, nor by the continued use of salt provisions ... but the privation for a considerable length of time of fresh succulent vegetables". ${ }^{54-57}$ AHG of the Royal Navy ("we never hear of scurvy on board a man-of-war ..." he wrote) also contributed to The Times correspondence. He observed, quite correctly, that most cases occurred during the homeward bound journey of a long voyage. "Is it, then [he asked that], the man's blood has become vitiated by long sojourn in [a] hot climate, by excesses committed on shore in the tropics, by a long sameness of food, or by his having absorbed a greater amount of salt from his long continuance upon salt provisions?" He continued, "... the men shipped for the run home are frequently deserters from other ships, who have been wallowing in the back slums of Calcutta, or some equally vile slums, until they are thoroughly contaminated, mind and body". "Good water [he concluded] is far more essential to health than even lime juice". ${ }^{64}$

Yet another aetiological theory involved alcoholism as being causative, but this suggestion was roundly debunked by Leach: "... we find that patients suffering from delirium tremens usually [he wrote] come to us [on the Dreadnought] from the best class vessels-i.e. those in which scurvy is known never to exist ...". ${ }^{39}$

\section{INQUESTS AND LITIGATION RELATING TO SCURVY DEATHS}

A sailor died (of scurvy) on board the St Andrew's Castle (see above), a 659 ton vessel lying at the time at St Katherine's Dock, which had sailed from Shanghai to London between 22 October 1865 and 16 February 1866; seven out of 13 crew members on board had been "disabled by scurvy". Leach pronounced that these "were the worst [cases of scurvy] he had ever seen" and that the so-called lime juice was lacking potency (see above). ${ }^{47}{ }^{65}$ An inquiry was conducted by the Middlesex coroner, and the jury returned the verdict "That the deceased died ... from exhaustion, scurvy, and dysentery" ${ }^{65}$ Another man on the same voyage also died later from scurvy-and this was the subject of a further inquest, this time conducted by the Kent coroner. The Coroner stated that the "firm which supplied the ship (with lime juice) were liable to a penalty of $20 \mathrm{l}$ [ that is $£ 20$ ] under the Merchant Shipping Act, a fine far too small ... for such an offence". He stated furthermore, that the "case of this ship would be brought under the notice of the House of Commons" ${ }^{\prime 66}$; this court "returned a verdict-" "That the deceased died from scurvy; and the jury further say that the juice shipped on board the St Andrew's Castle was a chymical decoction perfectly useless as a preventive for scurvy" ${ }^{\prime \prime}{ }^{47} 66$

A further outbreak of the disease involved the 1490 ton Riversdale, registered in the Port of Liverpool; six men had developed scurvy on the homeward journey from Calcutta (3 June to 26 September 1867), and all had joined the ship at Calcutta, a mere six days after arrival there in another vessel. These authors concluded that scurvy resulted from the fact that the affected sailors "had made two long oceanic voyages (with the interval of only six days), ... and to the consequent privation of fresh vegetable food for nearly eight months". The master, who was apparently aware that the lime juice was of "faulty character" was criticised for not procuring "a fresh supply at the Cape of Good Hope, or St. Helena"; the report stated that this was "the only point in which the requirements of the [existing 1854] Act do not seem to have been complied with ...". ${ }^{6768}$

\section{THE PROBLEM SOLVED}

The Times of 6 April $1867^{69}$ drew attention to a "voluminous Parliamentary paper, of 123 pages ... in continuation of that issued in June $1865^{\prime \prime} .{ }^{47}$ This paper in fact formed the basis for the Merchant Shipping Amendment Act of 1867 (fig 4) (see below). The Act stipulated that only lime or lemon juice containing $15 \%$ of "proper and palatable Proof Spirits" 
"obtained from a Bonded Warehouse" was acceptable "on board ... Ship", and furthermore that it must be accompanied by "a Certificate under the Hand of an Inspector appointed by the Board of Trade". The master of every ship was required to serve out an ounce each per day to every member of the crew of lime or lemon juice or "other such Anti-scorbutics ... as soon as they have been at sea for Ten Days, and during the Remainder of the Voyage, except during such Time as they are in Harbour and are there supplied with fresh Provisions". ${ }^{70}$ Leach had clearly taken a major role in the preparation of this work; significantly, only two out of 26 specimens of lime juice subsequently analysed were "declared genuine". The anonymous writer in The Times considered that the report contained a "most valuable resumé of facts for reference in connexion with the Mercantile Maritime Amendment Bill [which would soon be] introduced into the House of Lords under the auspices of the [sixth] Duke of Richmond [(1818-1903) President of the Board of Trade]". In fact, the Act took longer to implement than anticipated by the anonymous writer.

The Lancet summarised the major content of the Bill (although unsatisfactory conditions of accommodation were covered simultaneously), and emphasised "the examination of lime - and lemon - juice by certified medical officers, for its subsequent storage in bond, and for adding to it when so stored a certain amount of spirit [which had to] be added to the juice in the presence of the Customs Officer". The juice was to be "subject to visits of inspection from the officer appointed by the Board of Trade" and given daily to each man "at the rate of one ounce ... per diem". Any seaman "who refuses or neglects to drink it [the Bill stated] shall be reported in the log-book of the ship". ${ }^{71}$ The content(s) and implementation of the Bill (the Act eventually came into force on 1 January 1868) were outlined in greater detail in subsequent issues of The Lancet ${ }^{72-76}$; it was regretted by one writer that the Bill did not also cover venereal disease(s) from which "the merchant seaman suffers more ... than does any other class of the community". The 47th annual report of the SHS hailed the Bill (and subsequent Act, and welcomed the "Medical Inspection of Lime Juice before the Ship goes to sea") which was precisely what the Society had recommended. ${ }^{77}$

Under the amended Act, it became compulsory therefore for the ship's captain to provide lime juice of good quality to all men under his command. Figure 3 shows the sharp decline in cases of scurvy admitted to the Dreadnought hospital-ship after this Act had come into effect.

But despite the stringent provisions outlined in the Act, cases of scurvy continued to be admitted to the SHS hospitals in 1868 and beyond (albeit at a lesser rate). ${ }^{78-90}$ There were several reasons for this but probably the most important was

1296

\begin{tabular}{c}
$30^{\circ} \& 31^{\circ}$ VICTORIE, Cap. $124 . \quad$ [t. R. \\
\hline Merchant Shipping. \\
\hline
\end{tabular}

C A P. CXXIV. An Act to amend The Merchant Shipping Act, 1854. [20th August 1867.]

$B^{3}$ E it enacted by the Queen's most Excellent Majesty, by and with the Advice and Consent of the Lords Spiritual assembled, and by the Authority of the same, as follows :

Short Title. 1. This Act may be cited as The Merchant Shipping Act, 1867, and shall be construed with and as Part of The Merchant Shipping Act, 1854, herein-after termed the Principal Act.

Figure 4 Title page of An Act to amend the Merchant Shipping Act, 1854, published on 20 August 1867 (30 \& $31^{\circ}$ Victoriae, Cap 124). lack of adherence due to poor discipline; for example, "The Court ascribed the rapid spread of the disease [on board a Liverpool vessel, the Bremen $^{83}$ ] to the disinclination of the black members of the crew [it remains unclear as to what percentage were Lascars] to take lime-juice or compressed vegetables" $^{\prime 91}$; this latter term was a substitute for preserved (mixed) vegetables. Stone (see above) however, continued with his theme of 10 years previously, that is, that lime juice alone was insufficient to prevent the disease, and that preserved potatoes "are now universally admitted to possess all the antiscorbutic properties of the fresh potato". Another view expressed was that "mustard and cress" (easily grown on a wet blanket on board ship) had potent antiscorbutic qualities; this method had apparently been used in 1809 to prevent scurvy on a ship which formed part of a "fleet of East Indiamen" under the medical charge of James Haviland, FRCS. $^{92}$

Eventually scurvy in the Mercantile Marine was brought under control but not until the last days of the 19th century (fig 3). It had taken far longer to achieve than should have been the case, and the SHS (largely via the efforts of Harry Leach, Resident Medical Officer on board the Dreadnought hospital-ship) was very largely responsible for sweeping away this major scourge of the British Mercantile Marine.

\section{EPILOGUE}

In retrospect, it is arguable whether the recommended quantity or condition of the lime juice was in fact in itself sufficient to prevent scurvy; experimental studies have demonstrated that even genuine lime juice coming into contact with copper and/or as a result of other preservative procedures may become virtually inactive after a prolonged period of storage. ${ }^{93}$ Of course, there were also other factors in operation apart from the quantity/quality of lime (or lemon) juice alone; for example, the introduction of steam ships in the mid-19th century which led to much faster voyages, and it was then possible to stop at coaling stations where fresh food could be brought on board.

\section{REFERENCES}

1 Woodall J. The Surgions Mate, or a treatise discovering faithfully and plainely the due contents of the surgions chest, the uses of the instruments, the vertues and operations of the medicines, the cures of the most frequent diseases at sea: namely wounds, apostumes, ulcers, fistulaes, fractures, dislocations, with the true maner of amputation, the cure of the scurvie, the fluxes of the belly, of the collica and illiaca pastio, tenasmus, and exitus ani, the callenture; with a briefe explanation of sal, sulphur, and mercury; with certaine characters, and tearrmes of arte. London: Edward Griffin, 1617:348

2 Allison RS. Sea Diseases: the story of a great natural experiment in preventive medicine in the Royal Navy. London: John Bale Medical Publications Ltd, 1943:218.

3 Keay J. The Honourable Company: a history of the English East India Company. London: HarperCollins, 1991:475.

4 Rodger NAM. The wooden world: an anatomy of the Georgian Navy. London: Fontana Press, 1988:445.

5 Watt J. The medical bequest of disaster at sea: Commodore Anson's circumnavigation 1740-44. J R Coll Physicians 1998;32:572-9.

6 George, first Baron Anson (1697-1762) had a most distinguished naval career. He served as midshipman and lieutenant in the Baltic; second lieutenant; captain and commander on the Carolina Coast, West Indies and Pacific; rear-admiral; admiral of the fleet. He later became first Lord of the Admiralty (1751-6 and 1757-62). On his circumnavigation of 1740-4, 1385 out of 1854 men died of disease-most from scurvy.

7 Laughton JK. Anson, George, Lord Anson (1697-1762). In: Stephen L, Lee S, eds. Dictionary of Medical Biography 1908;1:503-8.

8 Lind J. A treatise of the scurvy, in three parts, containing an inquiry into the nature, causes, and cure of that disease. Together with a critical and chronological view of what has been published on the subject. Edinburgh: Sands, Murray and Cochran, 1753:456.

9 Harvie DI. Limeys: the true story of one man's war against ignorance, the establishment and the deadly scurvy. Stroud, Gloucestershire: Sutton Publishing, 2002:314.

10 Moore N. In: Lee S, eds. Dictionary of National Biography 1909;11:1150-1, James Lind (1716-94) obtained his MD from the University of Edinburgh, and was a fellow of the College of Physicians of Edinburgh. As a surgeon in the navy, he served at Minorca, the West Indies, Mediterranean and English Channel and from 1758-94 he was physician to the Naval Hospital, Haslar. 
In addition to his work on scurvy, he published: "An Essay on Diseases incidental to Europeans in Hot Climates".

11 Blane G. Observations on the Diseases Incidental to Seamen. London: Cooper, 1785:200.

12 Trotter T. Medicina Nautica: an essay on diseases of seamen in three volumes. 2nd Ed. London: Longman, Hurst, Rees \& Orme, 1804:1-405.

13 Blane G. Statements of the Comparative Health of the British Navy, from the year 1779 to the year 1814, with proposals for its farther improvement. Med Chir Trans 1815:6:490-573.

14 Lloyd C, Coulter JLS. Medicine and the Navy 1200-1900. Edinburgh: E \& S Livingstone Ltd, 1961;3:402.

15 Carpenter KJ. The History of Scurvy \& Vitamin C. Cambridge: Cambridge University Press, 1988:288.

16 Estes JW. Naval Surgeon: life and death at sea in the age of sail. Canton, MA; Science History Publications, 1998:266.

17 Barnes R. Report on the OCCURRENCE of SEA SCURVY in the MERCANTILE NAVY, based chiefly upon the Experience of the SEAMEN'S HOSPITAL Ship, "DREADNOUGHT", lying off GREENWICH. London: HM Stationery Office, 1864:330-49.

18 Anonymous. Scurvy in a ship of war. Times, London 1867;14 January, 8.

19 Anonymous. Twenty-first report of the Committee of the Seamen's Hospital Society. Under the Patronage of Her Majesty. Origins and Progress of the Seamen's Hospital Society for Sick and Diseased Seamen in the Port of London, on board the Dreadnought, 104 gun Ship, moored off Greenwich. Supported by Voluntary Contributions. Established in 1821 - incorporated in 1833. London: W Gilbert, 1842, 17-20.|lbid, Twenty-second report 1843:18-21. Ibid, Twenty-seventh report 1848:18-21. Ibid, Forty-third report 1864:18-21; Ibid, Forty-fourth report 1865:17-22; Ibid, Forty-fifth report 1866:17-21; lbid, Forty-sixth report, 1867:16-20.

20 George Budd MD, FRS (1808-1882) served as Visiting Physician to the Seamen's Hospital Society (SHS) at Greenwich from 1837-1840. Whilst there he became deeply interested in cholera and scurvy; in view of his work on the latter disease, he was invited by the Committee of the SHS to advise the Society on its cause and cure. He afterwards became Professor of Medicine at King's College, London..

21 Budd G. Scurvy. In: A Tweedie, ed. A system of Practical Medicine Comprised in a Series of Original Dissertations. London: Whittaker and $\mathrm{Co}_{\text {, }}$ 1840;5:58-95.

22 Cook GC. George Budd FRS (1808-1882): pioneer gastroenterologist and hepatologist. J Med Biog 1998;6:152-9.

23 Curnow J, Smith WJ. Tables of cases of scurvy, admitted from 1852 to 1889. In:W J Smith. A General Report of the cases under treatment at the Hospitals and Dispensaries of the Seamen's Hospital Society together with an analysis of the medical and surgical cases. Greenwich: E G Berryman \& Sons, 1892:28-9.

24 Anonymous. Tables of cases under treatment at the Hospitals and Dispensaries of the Seamen's Hospital Society in 1905. London: E G Berryman \& Sons, 1906:6

25 Cook GC. From the Greenwich hulks to Old St Pancras: a history of tropical disease in London. London: Athlone Press, 1992:33-67.

26 Cook GC. The Seamen's Hospital Society: a progenitor of the tropical institutions. Postgrad Med J 1999;75:715-17.

27 Earle P. Sailors: English merchant seamen 1650-1775. London: Methuen, 1998:259.

28 Anonymous. Leading article. Times, London 1866;10 January, 9.

29 Anonymous. Causes of Sea-Scurvy in the Mercantile Marine, Sixth report of the Medical Officer of the Privy Council, with appendix 1863. London: House of Commons, 1864:17-21.

30 Farrer TH, ed. Correspondence between the Board of Trade and the Local Marine Boards, or other Persons, on the subject of Scurvy in Merchant Ships, since the Date of the Sixth Report of the Medical Officer of the Privy Council, dated 1863; together with the Results of any Inquiries ordered by the Board of Trade in Cases where Scurvy has been known to exist on board Ship. Parliamentary Paper No 404. London: House of Commons, 1865;23 June, 47.

31 Anonymous. Merchant Shipping Act, 1854:17 \& 18 Victoriae, c104. A collection of the Public General Statutes, passed in the Seventeenth and Eighteenth Year of the Reign of her Majesty Queen Victoria: being the Second Session of the Sixteenth Parliament of the United Kingdom of Great Britain and Ireland, 440-441

32 Harry Leach (1836-79), qualified from St Bartholomew's Hospital and served most of his short professional career with the Seamen's Hospital Society. Having reached the position of Chief Medical Officer to the Dreadnought Hospital, he resigned to become first Port Medical Officer for the City of London. He made major contributions to the health of the mercantile marine (including prevention of scurvy) and published "The Ship Captain's Medical Guide". He died of pulmonary tuberculosis.

33 Leach H. Scurvy. Times, London 1866;12 January, 7 .

34 Leach H. Scurvy in the Merchant Navy. Times, London 1866;17 January, 7.

35 Leach H. Sea scurvy. Times, London 1866;19 February, 12.

36 Leach H. Marine scurvy. Times, London 1866;28 March, 12.

37 Leach H. Scurvy. Times, London 1867;8 January, 8.

38 Leach H. Lime juice. Times, London 1867:22 January, 9.

39 Leach H. Sea scurvy. Times, London 1867;29 January, 9

40 Cook GC. Harry Leach MRCP (1836-1879): control of scurvy in the British Mercantile Marine, and first Port Medical Officer for the City of London. J Med Biog 2000;8:133-9.

41 Picthall J. Scurvy. Times, London 1866;12 January, 7.
42 Armstrong R. Scurvy in the Merchant Navy. Times, London 1866;17 January, 7.

43 "Limejuice". Scurvy in the Merchant Navy. Times, London 1866;17 January, 7.

44 Anonymous. British-made scurvy. BMJ 1867;i:176-7.

45 Anonymous. Scurvy. BMJ 1867;i: 237.

46 Harrison WB. The St Andrew's Castle. Times, London 1866;6 March, 12.

47 Farrer TH, ed. Correspondence between the BOARD of TRADE and the Local MARINE BOARDS, or other Bodies or Persons, on the subject of SCURVY in MERCHANT SHIPS, together with the RESULTS of any INQUIRIES ordered by the BOARD of TRADE in cases where SCURVY has been known to exist on board Ship (in continuation of Parliamentary Paper, No 404, of Session 1865). London: House of Commons, 1867;13 March, 123.

48 Leach H. Sea-scurvy and limejuice. Times, London 1866;8 March, 12

49 Henderson Smith A. A historical inquiry into the efficacy of lime juice for the prevention and cure of scurvy. J R Army Med Corps 1919;32: 93-1 16, 188208).

50 Wilson LG. The clinical definition of scurvy and the discovery of vitamin C. J Med Hist \& Allied Sci 1975; 30:40-60.

51 [H W]. Limejuice and scurvy. Times, London 1866;12 December, 6.

52 King FJ. Scurvy. Times, London 1866;12 January, 7.

53 King FJ. Scurvy. Times, London 1876;25 August, 4.

54 Stone WD. Scurvy. Times, London 1866;1 March, 6.

55 Stone WD. Sea scurvy. Times, London 1866;10 December, 12

56 Stone WD. Scurvy. Times, London 1866;13 December, 4.

57 Stone WD. Scurvy. Times, London 1868;3 January, 8.

58 Anonymous. Scurvy on board ship. Times, London 1876;19 February, 5.

59 Anonymous. Scurvy. Times, London 1876;3 April, 7.

60 Anonymous. Scurvy. Times, London 1876;4 April, 5

61 Anonymous. Scurvy. Times, London 1876;6 April, 9 .

62 Estes JW. Op cit. See reference 16.

63 Farrer TH, ed. REPORTS, CORRESPONDENCE and PAPERS relating to recent Cases of Scurvy which have occurred on board BRITISH MERCHANT SHIPS. London: House of Commons, 1876;20 March, 182.

64 AHG. Sea scurvy. Times, London 1867;17 April, 12

65 Anonymous. Scurvy. Times, London 1866;21 February, 5.

66 Anonymous. Scurvy and adulterated limejuice. Times, London 1866;27 February, 9

67 Dickson W, Stuart JOP. Scurvy on board the Riversdale. Official Report. Times, London 1867;11 October, 10.

68 Farrer TH, ed. Correspondence between the Board of Trade or other Bodies or Persons on the Subject of SCURVY in MERCHANT SHIPS; together with the RESULTS of any INQUIRIES on the subject (in continuation of Parliamentary Paper, No 126, of Session 1867). London: House of Commons, 1871;8 August, 67.

69 Anonymous. Scurvy. Times, London 1867;6 April, 12.

70 Anonymous. An Act to amend The Merchant Shipping Act, $30^{\circ} \& 31^{\circ}$ Victoriae, Cap 1854;124 [20th August 1867] 1296-302.

71 Anonymous. Mercantile Marine Bill. Lancet 1867;i:800.

72 Anonymous. Leading article. Lancet 1867;ii: 18-19.

73 Anonymous. Lancet 1867:ii: 140 .

74 Anonymous. Lancet 1867;ii: 312 .

75 Anonymous. Lancet 1867;ii:530.

76 Anonymous. Lancet 1867;ii:622.

77 Anonymous. Forty-seventh report. Under the Patronage of Her Majesty. An account of the Origin and progress of the Seamen's Hospital Society, for sick and diseased seamen of all nations, in the Port of London, on board The Dreadnought, three-decker, moored off Greenwich, Supported by Voluntary Contributions. Established 1821, incorporated 1833. London: M \& W Collis, 1868, 16-20; Ibid.Forty-ninth report, 1870:15-19.

78 Anonymous. Scurvy. Times, London 1868;28 October, 12.

79 Anonymous. Scurvy. Times, London 1876;7 February, 4.

80 Anonymous. Scurvy. Times, London 1876;8 February, 6

81 Anonymous. The outbreak of scurvy. Times, London 1876;9 February, 10

82 Anonymous. Scurvy on board ship. Times, London 1876;26 February, 12

83 Anonymous. Scurvy. Times, London 1876;28 February, 5.

84 Anonymous. Scurvy. Times, London 1876;7 March, 9.

85 Anonymous. Scurvy. Times, London 1876;8 April, 11.

86 Anonymous. Scurvy. Times, London 1876:23 August, 4

87 Stone WD. Scurvy. Times, London 1876;24 August, 11.

88 Anonymous. Scurvy. Times, London 1876;17 October, 4

89 Farrer TH, ed. TABLES of REPORTS made to the Board of Trade relating to recent Cases of SCURVY which have occurred on board BRITISH MERCHANT SHIPS (in continuation of Parliamentary Paper, No 117, of Session 1876). London: House of Commons, 1879;28 July, 14.

90 Farrer TH. MEMORANDUM entitled MERCHANT SHIPS, SEA SCURVY, FOOD SCALES, ANTI-SCORBUTICS, together with the CORRESPONDENCE and PAPERS relating thereto (in continuation of Parliamentary Paper, No 319, of Session 1879). 1883;6 March, 27.

91 Farrer TH, ed. REPORT [written by $H$ Leach] recently received at the Board of Trade from the Medical Officer of the "Dreadnought" on the use of Dried or Preserved Vegetables for the Prevention of SCURVY in MERCHANT SHIPS. London: House of Commons, 1871;1 August, 1.

92 Anonymous. Scurvy. Times, London 1876;9 November, 7.

93 Chick $H$, Hume EM, Skelton RF, et al. The relative content of antiscorbutic principle in limes and lemons, together with some new facts and some old observations concerning the value of "lime juice" in the prevention of scurvy. Lancet 1918;ii:735-8. 